\section{Prevernalization Daily Light Integral and Vernalization Temperature Influences Flowering of Herbaceous Perennials}

\author{
Genhua Niu, Royal Heins ${ }^{1}$, Arthur Cameron, and William Carlson \\ Department of Horticulture, Michigan State University, East Lansing, \\ MI 48824-1325
}

Additional index words. Aquilegia $\times$ hybrida, Coreopsis grandiflora, Lavandula angustifolia, light quality

\begin{abstract}
The influence of daily light integral (DLI) before vernalization and vernalization temperature and duration on growth and flower development was determined for seedpropagated perennials Aquilegia $\times$ hybrida Sims 'Remembrance', Coreopsis grandiflora Hogg ex Sweet 'Sunray', and Lavandula angustifolia Mill. 'Hidcote Blue'. Seedlings were grown under two DLIs ( 4 or $14 \mathrm{~mol} \cdot \mathrm{m}^{-2} \cdot \mathrm{d}^{-1}$ ) for 5 weeks before being vernalized at $\mathbf{- 2 . 5}, 0$, 2.5 , or $5{ }^{\circ} \mathrm{C}$ for $2,4,5$, or 8 weeks. 'Remembrance' and 'Sunray' plants were vernalized in the dark, while 'Hidcote Blue' plants were vernalized in light at 5 to $10 \mu \mathrm{mol} \cdot \mathrm{m}^{-2} \cdot \mathrm{s}^{-1}$ for 9 hours/day. After vernalization, plants were forced under a 16-h photoperiod in the greenhouse at $20 \pm 2{ }^{\circ} \mathrm{C}$. 'Remembrance' plants flowered uniformly when vernalized at 0 to $2.5{ }^{\circ} \mathrm{C}$ for 2 weeks or longer, and flower number, plant height, time to visible bud or to flower were generally not influenced by vernalization temperature or duration. No 'Sunray' plants flowered without vernalization, and only a low percentage flowered with 4-week vernalization. Compared with low DLI, a $14 \mathrm{~mol} \cdot \mathrm{m}^{-2} \cdot \mathrm{d}^{-1}$ before vernalization delayed flowering by 7 to 20 days in 'Remembrance', but there were no substantial differences in flowering characteristics of 'Sunray'. 'Hidcote Blue' plants were best vernalized in the light at $5{ }^{\circ} \mathrm{C}$ for 8 weeks to obtain rapid and uniform flowering and the highest number of inflorescences. Flowering and survival percentages of 'Hidcote Blue' were much lower for plants at $14 \mathrm{~mol} \cdot \mathrm{m}^{-2} \cdot \mathrm{d}^{-1} \mathrm{DLI}$ compared to $4 \mathrm{~mol} \cdot \mathrm{m}^{-2} \cdot \mathrm{d}^{-1}$.
\end{abstract}

The sale of herbaceous perennials in garden centers and other retail outlets has increased significantly in recent years. Many consumers prefer to purchase plants in flower, especially when buying unfamiliar species (Heins et al., 1997).

Conditions required to initiate flowering in herbaceous perennials vary by species. Some perennials require vernalization, some require photoperiodic manipulation, and others require both to induce flowering (Thomas, 1993). Vernalization has been defined as a cold treatment that promotes flowering of imbibed seeds, bulbs, or whole plants (Vince-Prue, 1975). The effectiveness of vernalization is governed by two groups of factors; genetics and the environment, including temperature, light intensity, and photoperiod (Napp-Zinn, 1987). Considerable research has been conducted to characterize flowering responses to photoperiod, vernalization duration, and growing temperature for a wide range of herbaceous perennials (Armitage and Garner, 1999; Heins et al., 1997; Whitman et al., 1997). However, the effect of irradiance before, during, and after cold treatment on growth and flower development is not well understood for most herbaceous perennials. From a practical point of

Received for publication 20 Aug. 2001. Accepted for publication $25 \mathrm{Feb} .2002$.

${ }^{1}$ To whom reprint requests should be addressed. E-mail: heins@msu.edu view, vernalizing perennials in the dark would be simpler and less expensive for producers.

Irradiance before or during vernalization affects vernalization responses in some plants. For example, in Allium cepa L. low light intensity during vernalization reduced flower initiation only when plants had been grown at high temperatures $\left(25^{\circ} \mathrm{C}\right)$ and low light intensity before vernalization (Brewster, 1985). In Triticum aestivum $\mathrm{L}$., vernalization was more effective under long days than under short days when light intensities were low $(\approx 2000$ lux), and the influence of photoperiod was reduced when light intensity was increased; vernalization did not take place in the dark unless $2 \%$ sucrose was added to the culture medium (Krekule, 1987). These results suggest that plants must have a critical amount of carbohydrates for vernalization to take place. In addition to irradiance, light quality also influences flower development in some longday plants (Runkle and Heins, 2001). Light quality before vernalization interacted with vernalization in Arabidopsis thaliana L. $f c a$ late flowering mutant: the delay of flowering was decreased by vernalization (Bagnall, 1993).

Aquilegia $\times$ hybrida is a hardy herbaceous perennial produced for landscape and cutflower use (Gianfagna and Merritt, 1998). Vernalization and long-day photoperiods enhanced growth and flowering in some cultivars (Garner and Armitage, 1998), while no vernalization was necessary for flowering in other cultivars (White et al., 1990a; Zhang et al., 1991). Shedron and Weiler (1982) reported that for flower induction, plants needed neither light nor leaves during vernalization. Overall, vernalization requirements varied among cultivars; no information is available on 'Remembrance'.

The recommended flowering conditions for Coreopsis grandiflora 'Sunray' are 10 weeks vernalization at $\approx 5^{\circ} \mathrm{C}$, long days after vernalization, and minimum of eight nodes; extending vernalization from 10 to 15 weeks enhanced flowering percentage on marginally mature plants but did not influence time to flower (Yuan et al., 1998). Vernalization for at least 10 weeks at $5^{\circ} \mathrm{C}$ was recommended for commercial production of Lavandula angustifolia 'Munstead' (Whitman et al., 1996a) and 'Hidcote Blue' (Whitman et al., 1996b).

The objective of this study was to investigate the influence of light intensity before vernalization and subsequent vernalization temperature and duration on growth and flower development of A. Xhybrida 'Remembrance', C. grandiflora 'Sunray', and L. angustifolia 'Hidcote Blue'.

\section{Materials and Methods}

Plant materials and culture. Aquilegia $\times$ hybrida 'Remembrance' seedlings with seven to nine leaves in 72 -cell trays $(50-\mathrm{mL}$ cell volume) were received from a commercial producer on 9 Sept. 1999 and were transplanted to 36 -cell trays ( $120-\mathrm{mL}$ cell volume) on 20 Sept. 1999. On 8 Sept. 1999, a commercial producer seeded L. angustifolia 'Hidcote Blue' and C. grandiflora 'Sunray' in 72-cell trays. Seedlings were delivered to Michigan State Univ, on 18 Dec. 1999. Upon arrival, seedlings were transplanted to $13-\mathrm{cm}$ square plastic (1.1-L volume) containers.

A peat-perlite mix (Sure-Mix; Michigan Grower Products, Galesburg, Mich.) was used as the potting medium for all the species. Plants were placed in a greenhouse maintained at $20 \pm 2{ }^{\circ} \mathrm{C}$ under natural daylength before treatment. They were top-watered as necessary with a nutrient solution of well water acidified with $\mathrm{H}_{2} \mathrm{SO}_{4}$ to a titratable alkalinity of $\approx 130 \mathrm{mg} \mathrm{CaCO}_{3} / \mathrm{L}$ and water soluble fertilizer composed of $125 \mathrm{~N}-12 \mathrm{P}-125 \mathrm{~K}-$ $13 \mathrm{Ca}\left(\mathrm{mg} \cdot \mathrm{L}^{-1}\right)$ plus $1.0 \mathrm{Fe}-0.5 \mathrm{Mn}-0.5 \mathrm{Zn}-$ $0.5 \mathrm{Cu}-0.1 \mathrm{~B}-0.1 \mathrm{Mo}\left(\mathrm{mg} \cdot \mathrm{L}^{-1}\right.$, MSU Special; Greencare Fertilizers, Chicago).

Experimental design. Plants were grown under two daily light integrals (DLI; 400 to $700 \mathrm{~nm}$ wave band) before vernalization for 5 weeks in a greenhouse maintained at $20 \pm 2$ ${ }^{\circ} \mathrm{C}$ under a 12-h photoperiod ('Remembrance', from 29 Oct. 1999 to 3 Dec. 1999; 'Hidcote Blue' and 'Sunray', from 22 Dec. 1999 to 26 Jan. 2000). The two DLIs were created by supplementing natural sunlight with high-pressure sodium (HPS) lamps at $0 \mu \mathrm{mol} \cdot \mathrm{m}^{-2} \cdot \mathrm{s}^{-1}$ (without supplementing) or $\approx 200 \mu \mathrm{mol} \cdot \mathrm{m}^{-2} \cdot \mathrm{s}^{-1}$ photosynthetic photon flux $(P P F)$. $P P F$ was measured at plant canopy level using a line quantum sen- 
sor that included 18 photodiodes (G2711; Hamamatsu Co., Hamamatusu, Japan) linked to a Campbell Scientific CR-10 datalogger (Logan, Utah). The actual DLIs throughout the experimental period were calculated to be 4 and $14 \mathrm{~mol} \cdot \mathrm{m}^{-2} \cdot \mathrm{d}^{-1}$ for low and high DLIs, respectively, based on the measured $P P F$. The node number after the 5-week DLI treatment was $\approx 28,27$, and 29 for 'Remembrance', 'Sunray', and 'Hidcote Blue', respectively, regardless of DLI. Plants were then vernalized in coolers set at $-2.5,0,2.5$, or $5^{\circ} \mathrm{C}$ for $2,4,6$, or 8 weeks, respectively. For temperatures of $-2.5^{\circ} \mathrm{C}$ and $0^{\circ} \mathrm{C}$, plants were moved to a cooler set at $5^{\circ} \mathrm{C}$ for $3 \mathrm{~d}$ for hardening before moving to the -2.5 or $0^{\circ} \mathrm{C}$ cooler. 'Remembrance' and 'Sunray' were vernalized in darkness by covering plants with black plastic sheets to exclude light. 'Hidcote Blue' plants were vernalized with $5-10 \mu \mathrm{mol} \cdot \mathrm{m}^{-2} \cdot \mathrm{s}^{-1}$ for $9 \mathrm{~h} / \mathrm{d}$ provided by fluorescent lamps, because this plant did not survive vernalization at $5^{\circ} \mathrm{C}$ in the dark in a preliminary experiment. While in the coolers, plants were watered with well water $\left(\mathrm{CaCO}_{3}\right.$ at $\left.340 \mathrm{mg} \cdot \mathrm{L}^{-\mathrm{i}}\right)$ acidified $\left(93 \% \mathrm{H}_{2} \mathrm{SO}_{4}\right)$ to a titratable alkalinity of $\mathrm{CaCO}_{3}$ at 100 $\mathrm{mg} \cdot \mathrm{L}^{-1}$. After vernalization, plants were forced in a greenhouse maintained at $20 \pm 2{ }^{\circ} \mathrm{C}$ under long days created by extending natural daylength to $16 \mathrm{~h} / \mathrm{d}$ provided by HPS at $P P F$ of $65 \mu \mathrm{mol} \cdot \mathrm{m}^{-2} \cdot \mathrm{s}^{-1}$, measured by a line quantum sensor as described above. The experiment was a split-plot design with DLI before vernalization ( 2 levels) as the main plot, vernalization temperatures (4 levels) as the split plot, and vernalization durations (4 levels) as the split split plot. There were 10 plants per treatment for each species.

Data collection and analysis. The following data were collected: survival and flowering percentages of surviving plants, dates of visible bud and flowering, number of flower buds or inflorescences and plant height at flower, and node numbers developed after vernalization. Statistical Analysis System's (SAS Institute, Cary, N.C.) PROC MEAN was used to calculate the means and $95 \%$ confidence intervals and General Linear Model was used to test the significance of the treatments. Data were analyzed separately by species.

\section{Results}

Aquilegia $\times$ hybrida 'Remembrance'. More than $80 \%$ of the plants vernalized at 0 or $2.5^{\circ} \mathrm{C}$ in darkness for 2 to 8 weeks and those at $5{ }^{\circ} \mathrm{C}$ for 2 to 6 weeks survived (Fig. 1A-D), regardless of DLI before vernalization. At $-2.5^{\circ} \mathrm{C}$, the percentage of surviving plants in high DLI decreased from 90 to 50 as vernalization duration increased from 2 to 8 weeks, while the majority of the plants in low DLI survived. All the surviving plants in low DLI flowered uniformly when vernalized at 0 to $5{ }^{\circ} \mathrm{C}$, regardless of vernalization duration (Fig. 1E$\mathrm{H})$. Flowering percentage decreased from 90 to 40 as vernalization duration at $-2.5^{\circ} \mathrm{C}$ increased from 2 to 8 weeks when plants were in high DLI. The flowering percentage of unvernalized plants was 90 or 40 for plants in low or high DLI (data not shown).

Flowering was delayed by 5 to $20 \mathrm{~d}$ for plants in high DLI compared with low DLI when they were vernalized at -2.5 to $2.5^{\circ} \mathrm{C}$ (Fig. 1I-P). Flowering of unvernalized plants took $21 \mathrm{~d}$ longer under high DLI (data not shown). Time to visible bud or to flower was not influenced significantly by vernalization duration (Table 1). Data analysis for Table 1 excluded those plants vernalized at $-2.5^{\circ} \mathrm{C}$ because of low survival and flowering percentages.

The number of nodes that developed after vernalization was significantly higher for the plants in high DLI (Fig. 1Q-T; Table 1). Plant height and flower number were influenced by vernalization temperature and duration (Table 1), but there was no substantial difference between 0 and $2.5^{\circ} \mathrm{C}$ regardless of vernalization duration (Fig. 1U-AB). Plants vernalized at $-2.5^{\circ} \mathrm{C}$ generally were shorter and had fewer flower buds.

Coreopsis grandiflora 'Sunray'. No plants flowered without vernalization. Survival percentage decreased from 100 to 0 as duration at $-2.5^{\circ} \mathrm{C}$ increased from 2 to 8 weeks. There were minor differences in flowering characteristics except for flowering percentage among treatments. DLI before vernalization did not influence flowering characteristics. Flowering percentage based on pooled data from both

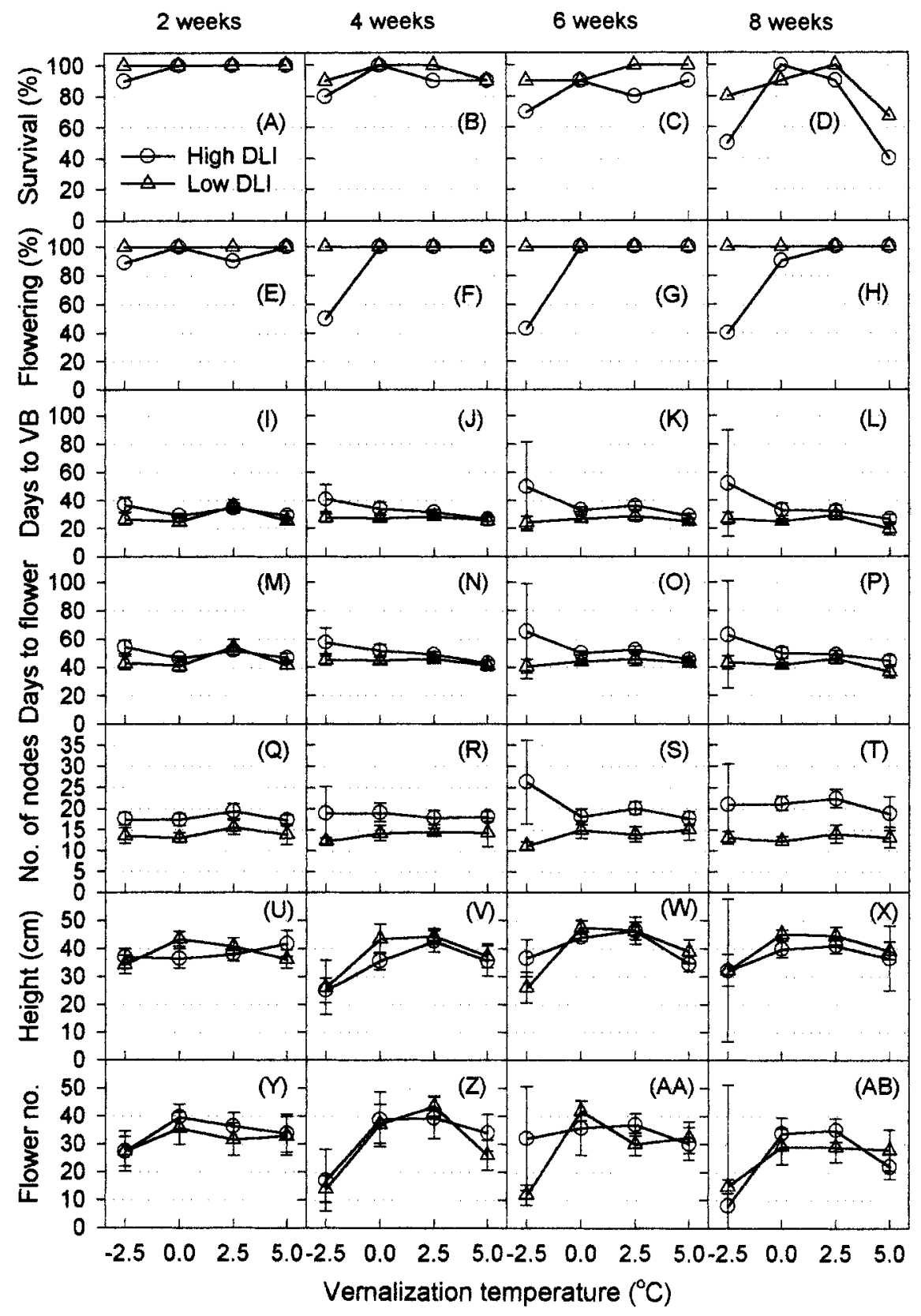

Fig. 1. Flowering of Aquilegia $\times$ hybrida 'Remembrance' grown under two daily light integrals (4 or 14 $\mathrm{mol} \cdot \mathrm{m}^{-2} \cdot \mathrm{d}^{-1}$ ) with a 12 -h photoperiod for 5 weeks before being vernalized at $-2.5,0,2.5$, or $5^{\circ} \mathrm{C}$ for $2,4,6$, or 8 weeks in darkness. The " 2 weeks, 4 , weeks, 6 weeks, and 8 weeks" indicate the vernalization durations for the seven graphs underneath, respectively. Error bars represent $95 \%$ confidence intervals. 


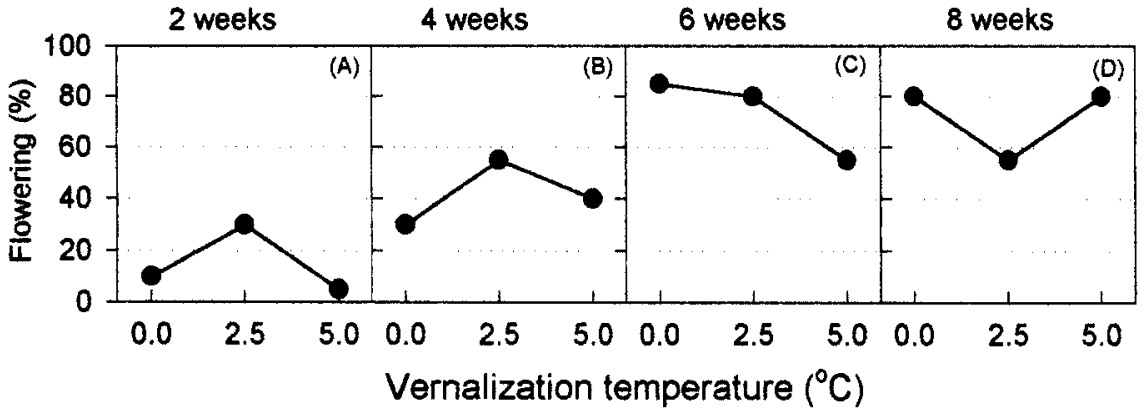

Fig. 2. Flowering percentage of Coreopsis grandiflora 'Sunray' grown under two daily light integrals ( 4 or 14 $\mathrm{mol} \cdot \mathrm{m}^{-2} \cdot \mathrm{d}^{-1}$, data pooled) with a 12 -h photoperiod for 5 weeks before being vernalized at $0,2.5$, or $5^{\circ} \mathrm{C}$ for $2,4,6$, or 8 weeks in darkness. The vernalization durations are shown on top of the graphs, respectively.

DLI treatments was below 60 for plants vernalized at 0 to $5^{\circ} \mathrm{C}$ for 4 weeks and more than 50 for plants vernalized for 6 to 8 weeks (Fig. 2). Generally, flowering percentage increased as vernalization duration increased.

Lavandula angustifolia 'Hidcote Blue'. Plants did not survive when vernalized at -2.5
${ }^{\circ} \mathrm{C}$, regardless of DLI before vernalization. No plants under high DLI and vernalized at 0 or $2.5^{\circ} \mathrm{C}$ for 6 or 8 weeks survived (Fig. $3 \mathrm{C}$ and D), while $50 \%$ to $60 \%$ plants under low DLI and vernalized at 0 or $2.5^{\circ} \mathrm{C}$ for 6 weeks survived (Fig. $3 \mathrm{C}$ ). When vernalized at $5^{\circ} \mathrm{C}$ for 6 or 8 weeks, all plants survived and

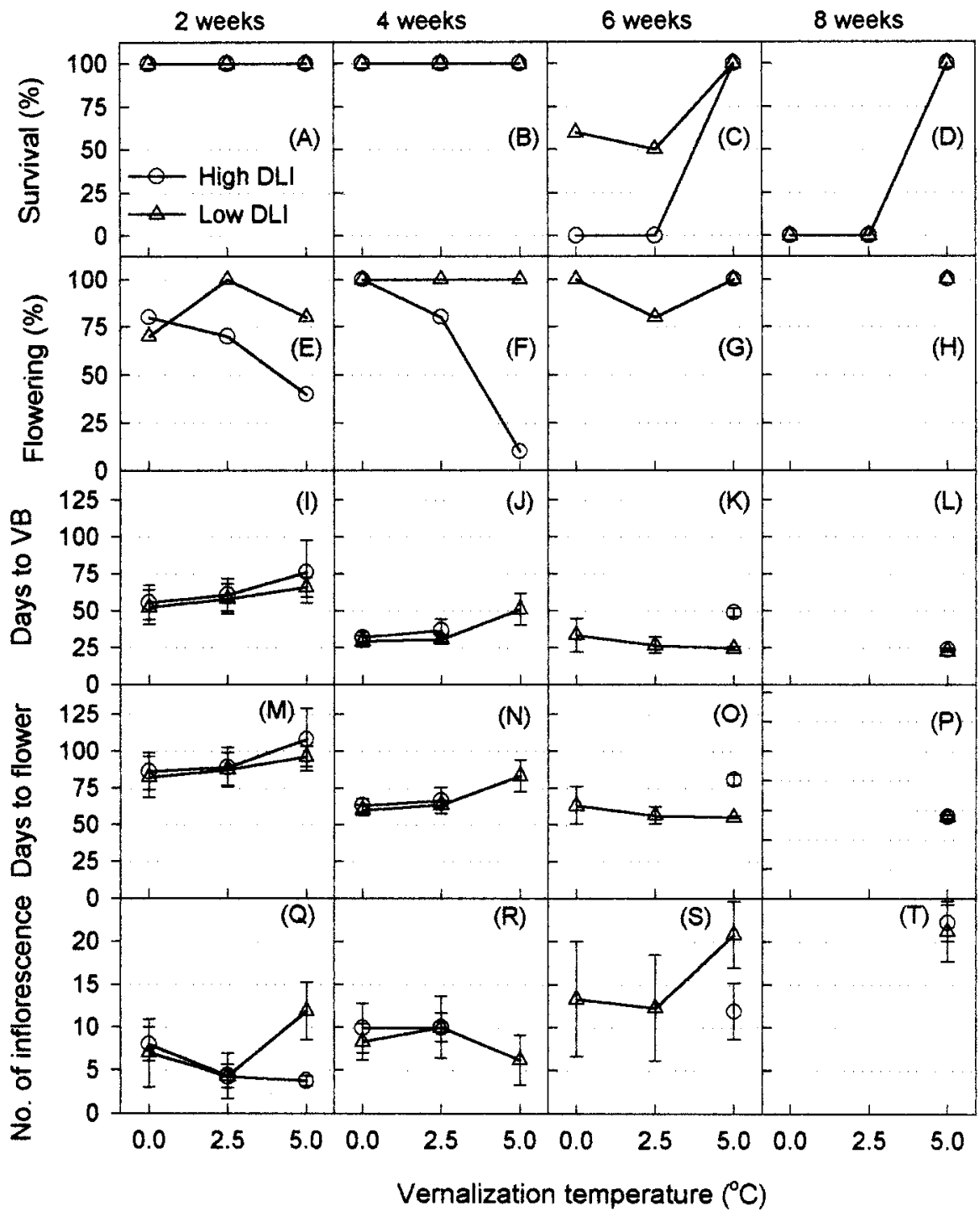

Fig. 3. Flowering of Lavandula angustifolia 'Hidcote Blue' grown under two daily light integrals ( 4 or 14 $\mathrm{mol} \cdot \mathrm{m}^{-2} \cdot \mathrm{d}^{-1}$ ) with a $12-\mathrm{h}$ photoperiod for 5 weeks before being vernalized at $0,2.5$, or $5^{\circ} \mathrm{C}$ for $2,4,6$, or 8 weeks in light. The " 2 weeks, 4 , weeks, 6 weeks, and 8 weeks" indicate the vernalization durations for the five graphs underneath, respectively. Error bars represent $95 \%$ confidence intervals. flowered, regardless of DLI (Fig. 3 C and D). All plants under low DLI and vernalized at 0 to $5^{\circ} \mathrm{C}$ for 4 weeks flowered (Fig. 3F). There was no significant difference in time to visible bud or flower among the plants under the two DLIs when plants were vernalized at $5{ }^{\circ} \mathrm{C}$ for 8 weeks (Fig. $3 \mathrm{~L}$ and P). However, when plants were vernalized at $5{ }^{\circ} \mathrm{C}$ for 6 weeks, time to visible bud or flower was delayed $25 \mathrm{~d}$, and plants had $\approx 45 \%$ fewer inflorescences under high DLI (Fig. $3 \mathrm{~K}, \mathrm{O}$, and S). Number of inflorescences was more than double on plants vernalized at $5^{\circ} \mathrm{C}$ for 8 weeks compared with that of plants vernalized at 0 or $2.5^{\circ} \mathrm{C}$ for 2 to 6 weeks (Fig. 3Q-T). As vernalization duration at $5{ }^{\circ} \mathrm{C}$ increased, number of inflorescences increased and time to flower decreased. The flowering percentage for unvernalized plants was only 40 , with an average of three inflorescences per pot, and plants took more than $100 \mathrm{~d}$ to flower, regardless of DLI before vernalization.

\section{Discussion}

Based on the research with A. cepa and $T$. aestivum where some minimal amount of carbohydrate was necessary for vernalization (Brewster, 1985; Krekule, 1987), we expected that a high DLI before vernalization would load plants with carbohydrates and might help vernalization to occur when plants were cold-treated in the dark. However, our results showed that 'Remembrance' seedlings pretreated with either 4 or $14 \mathrm{~mol} \cdot \mathrm{m}^{-2} \cdot \mathrm{d}^{-1}$ survived 8 -week vernalization in the dark and subsequently flower, but in some treatments for 'Hidcote Blue' $14 \mathrm{~mol} \cdot \mathrm{m}^{-2} \cdot \mathrm{d}^{-1}$ rather than $4 \mathrm{~mol} \cdot \mathrm{m}^{-2} \cdot \mathrm{d}^{-1}$ before vernalization reduced flowering percentage and delayed flowering.

Both hardening prior to low-temperature treatment and the actual plant storage method play an important role in the survival and subsequent growth of plants held in coolers. Engle (1994) reported that $L$. angustifolia 'Munstead' seedlings in 128-cell trays could survive 6 weeks' vernalization at $-2.5^{\circ} \mathrm{C}$ in darkness. In her experiment, seedlings growing in 128-cell trays were sealed in polyethylene packages and then hardened for 0 to 4 weeks at 0 or $5{ }^{\circ} \mathrm{C}$ under $50 \mu \mathrm{mol} \cdot \mathrm{m}^{-2} \cdot \mathrm{s}^{-1}$. Survival and regrowth ability of 'Munstead' seedlings following storage at $-2.5^{\circ} \mathrm{C}$ for 6 weeks were improved by hardening for 2 weeks or longer under light (Engle, 1994). In our experiment, plants of 'Hidcote Blue' were in $10-\mathrm{cm}$ round pots without protection and were hardened at $5^{\circ} \mathrm{C}$ for only $3 \mathrm{~d}$. Most of these plants did not survive 6 weeks of 0 or $2.5^{\circ} \mathrm{C}$ storage, suggesting that the hardening period was not sufficient, or the innate hardiness and response to vernalization may be different among $L$. angustifolia cultivars.

Flowering of some long-day plants is delayed when plants are grown under light sources with high ratios of red to far-red light, such as cool-white fluorescent (CWF) lamps (Runkle and Heins, 2001). Flowering was delayed by 10 to $44 \mathrm{~d}$ in Hyoscyamus niger L., Beta vulgaris L., Anethum graveolens L., and Petu- 
Table 1. A summary of analysis of variance for the effects of daily light integral (DLI $=4$ or 14 $\left.\mathrm{mol} \cdot \mathrm{m}^{-2} \cdot \mathrm{d}^{-1}\right)$ before vernalization, vernalization temperature $\left(\mathrm{Temp}=0,2.5\right.$, or $5^{\circ} \mathrm{C}$ ), and vernalization duration (Week $=2,4,6$, or 8 weeks) on days to visible buds (VB), days to flower (Flower), plant height, flower number (Flw no.), and node number of Aquilegia $\times$ hybrida 'Remembrance'. Data on plants vernalized at $-2.5^{\circ} \mathrm{C}$ were excluded because of low survival percentages.

\begin{tabular}{|c|c|c|c|c|c|}
\hline & VB & Flower & Height & Flw no. & Node no. \\
\hline$\overline{\mathrm{DLI}}$ & $* * *$ & $* * *$ & $* * *$ & NS & $* * *$ \\
\hline Temp & $* * *$ & $* * *$ & $* * *$ & $* * *$ & NS \\
\hline DLI $\times$ Temp & NS & $*$ & $*$ & NS & NS \\
\hline Week & NS & NS & $* *$ & $* *$ & $* * *$ \\
\hline DLI × Week & NS & NS & NS & NS & $* *$ \\
\hline Temp $\times$ Week & 党 & $* * *$ & $*$ & NS & NS \\
\hline DLI $\times$ Temp $\times$ Week & NS & NS & NS & NS & NS \\
\hline
\end{tabular}

nia hybrida Vilm. plants grown under CWF (Lane et al., 1965). White et al. (1990b) reported that $A$. Xhybrida 'Bluebird', 'Dove', and 'Robin' plants grown in the greenhouse under natural daylengths initiated flower buds before vernalization 5 months after sowing. However, the same cultivars did not initiate flower buds even 7 months after sowing when grown in a growth chamber at $20^{\circ} \mathrm{C}$, under photoperiods of $8,12,16$, or $20 \mathrm{~h} / \mathrm{d}$ and a DLI of $10.2 \mathrm{~mol} \cdot \mathrm{m}^{-2} \cdot \mathrm{d}^{-1}$ provided by CWF lamps (White et al., 1990b). In our study, 90\% of 'Remembrance' plants under low DLI flowered without vernalization, while only $40 \%$ of the plants under high DLI flowered, and they took an additional 3 weeks to flower. The high DLI was obtained by supplementing sunlight with HPS lamps. The ratio of red to far-red light is 5.9 for HPS, 8.8 for CWF, and 1.1 for sunlight (Whitman et al., 1998). The light quality may have a carry-over effect on the subsequent growth and flowering of the plants and requires further study.

The vernalization requirement for flowering of $A, \times$ hybrida varies with cultivar. In our study, 'Remembrance' plants flowered when vernalized for 2 weeks or longer at 0 to $5^{\circ} \mathrm{C}$, Unvernalized plants all flowered when grown under the low DLI before vernalization. 'Bluebird' and 'Robin' (White et al., 1990a), 'RoseWhite' (Gianfagna and Merritt, 1998), and 'Purple' and 'Dove' (Zhang et al., 1991) plants also flowered without vernalization, while 'Fairyland' and 'McKana's Giant' (Shedron and Weiler, 1982) required vernalization. Even for vernalization-requiring plants, the duration can vary between cultivars. For example, 10 weeks is required in 'McKana's Giant' plants, while only 4 weeks of vernalization is enough in 'Fairyland' (Shedron and Weiler, 1982) to achieve $100 \%$ flowering.

Flowering percentage of $C$. grandifolia 'Sunray' was not influenced by DLI but generally increased with vernalization duration, and there was no general pattern on optimal vernalization temperature in this experiment. Damann and Lyons (1996) reported that 4 months natural chilling followed by continuous short-day or long-day conditions resulted in $40 \%$ or $90 \%$ flowering in 'Sunray', respec- tively, and only $20 \%$ flowered for unchilled plants. No plants flowered without vernalization in any short-day or long-day conditions (Damann and Lyons, 1993), which is in agreement with our present study.

In summary, because of poor plant performance and low survival percentage, vernalization in the dark at $-2.5^{\circ} \mathrm{C}$ is not recommended for the species tested in this study, unless plants are hardened and handled in special ways, e.g., sealed in plastic bags. Supplemental lighting from HPS lamps before vernalization is unnecessary and in fact should be avoided for these species, because in some cases high DLI before vernalization hampered subsequent growth and flowering. 'Remembrance' plants flowered without vernalization or were vernalized by only 2 weeks at 0 to $5^{\circ} \mathrm{C}$ in darkness. 'Hidcote Blue' plants can be vernalized in light at $5^{\circ} \mathrm{C}$ for at least 8 weeks to ensure $100 \%$ flowering and numerous flowers. Flowering response of 'Sunray' was not uniform in most treatments; flowering percentage generally increased as vernalization duration increased.

\section{Literature Cited}

Armitage, A. and J. Garner. 1999. Photoperiod and cooling duration influence growth and flowering of six herbaceous perennials. J. Hort. Sci. Biotechnol. 74:170-174.

Bagnall, D.J. 1993. Light quality and vernalization interact in controlling late flowering in Arabidopsis ecotypes and mutants. Ann. Bot. 71:75-83.

Brewster, J.L. 1985. The influence of seedling size and carbohydrate status, and of photo flux density during vernalization on inflorescence initiation in onion (Allium cepa L.). Ann. Bot. 55:403414.

Damann, M.P. and R.E. Lyons. 1996. Natural chilling and limited inductive photoperiod affect flowering in two Asteraceae genera. J. Amer. Soc. Hort. Sci. 121:694-698.

Engle, B.E. 1994. Use of light and temperature for hardening of herbaceous perennial plugs prior to storage at $-2.5^{\circ} \mathrm{C}$. MS Thesis, Dept. of Horticulture, Michigan State Univ., East Lansing.

Garner, J.M. and A.M. Armitage. 1998. Influence of cooling and photoperiod on growth and flowering of Aquilegia L. cultivars. Scientia Hort. 75:83-90.
Gianfagna, T.J. and R.H. Merritt. 1998. GA 4 promotes stem growth and flowering in a genetic line of Aquilegia $\times$ hybrida Sims. Plant Growth Regulat. 24:1-5.

Heins, R.D., A.C. Cameron, W.H. Carlson, E. Runkle, C. Whitman, M. Yuan, C. Hamaker, B. Engle, and P. Koreman. 1997. Controlled flowering of herbaceous perennial plants, p. 15-31 In: Goto et al. (eds.). Plant production in closed ecosystems. Kluwer Academic Publishers, The Netherlands.

Krekule, J. 1987. Vernalization in wheat, p. 159169. In: J.G. Atherton (ed.). Manipulation of flowering. Butterworths, London.

Lane, H., H. Cathey, and L. Evans. 1965. The dependence of flowering in several long-day plants on the spectral composition of light extending the photoperiod. Amer. J. Bot. 52:10061014.

Napp-Zinn, K. 1987. Vernalization-Environmental and genetic regulation, p. 123-132. In: J.G. Atherton (ed.). Manipulation of flowering. Butterworths, London.

Runkle, E.S. and R.D. Heins. 2001. Specific functions of red, far red, and blue light in flowering and stem extension of long-day plants. J. Amer. Soc. Hort. Sci. 126:275-282.

SAS Institute. 1989. SAS/STAT user's guide. Version 6.12. SAS Inst., Cary, N.C.

Shedron, K.G. and T.C. Weiler. 1982. Regulation of growth and flowering in Aquilegia $\times$ hybrida Sims. J. Amer. Soc. Hort. Sci. 107:878-882.

Thomas, B. 1993. The role of phytochrome and other photoreceptors in the control of flowering in long-day plants. Flowering Nwsl. 16:6-10.

Vince-Prue, D. 1975. Photoperiodism in plants. McGraw Hill, London.

White, J.W., H. Chen, and D.J. Beattie. 1990a. Gibberellin, light, and low-temperature effects on flowering of Aquilegia. HortScience 25:1422-1424.

White, J.W., H. Chen, X. Zhang, D.J. Beattie, and H. Grossman. 1990b. Floral initiation and development in Aquilegia. HortScience 25:294-296.

Whitman, C., R.D. Heins, A.C. Cameron, and W.H. Carlson. 1996a. Cold treatment, photoperiod, and forcing temperatures influence flowering of Lavandula angustifolia. HortScience 31:11501153.

Whitman, C., R.D. Heins, A.C. Cameron, and W.H. Carlson. 1996b. Forcing perennials-Crop by crop. Greenhouse Grower 14(5):37-40.

Whitman, C., R.D. Heins, A.C. Cameron, and W.H. Carlson. 1997. Cold treatment and forcing temperature influence flowering of Campanula carpatica 'Blue Clips'. HortScience 32:861865.

Whitman C., R.D. Heins, A.C. Cameron, and W.H. Carlson. 1998. Lamp type and irradiance level for daylength extensions influence flowering of Campanula carpatica 'Blue Clips', Coreopsis grandiflora 'Early Sunrise', and Coreopsis verticillata 'Moonbeam'. J. Amer. Soc. Hort. Sci. 123:802-807.

Yuan, M., W.H. Carlson, R.D. Heins, and A.C. Cameron. 1998. Determining the duration of the juvenile phase of Coreopsis grandiflora (Hogg ex Sweet.), Gailardia $\times$ grandiflora (Van Houtte), Heuchera sanguinea (Engelm.) and Rudbeckia fulgida (Ait.). Scientia Hort.

Zhang, X., J.W. White, and D.J. Beattie. 1991. Regulation of flowering in Aquilegia. J. Amer. Soc. Hort. Sci. 116:792-797. 